\title{
Analysis of Customer Satisfaction in Construction Companies Using QFD Method
}

\author{
Dharma Suhada and Bambang Syairuddin \\ Departement of Management Technology, Institut Teknologi Sepuluh Nopember (ITS) \\ e-mail:darmammt@gmail.com
}

\begin{abstract}
The study adapted the QFD model as main framework for analyzing service quality by using of service quality dimensions (tangibility, reliability, responsiveness, assurance, and empathy. The research used the questionnaires that were distributed between twenty respondents who are the consumers of that company. The survey analyzed the consumers' needs of houses and the ways for improving the quality of services. The outcomes of the study display that the top priority for customer satisfaction, such as name the suitability of the project report with actual conditions in the field; Ability to complete within deadlines; Service level after completion; Application of work procedures and instructions for completing projects; Project workers' expertise in using equipment in the field; Level of trust in communication followup; Discipline and compliance with agreed project schedules and Fulfillment of construction functions. While the technical response given by the company to increase consumer satisfaction are Monitoring the results of reports with the field by Project Control; Training of contractor field supervisors; Monitoring the communication system periodically; Training in the use of work equipment; Periodic $S$ curve monitoring; Improved technical communication between the person in charge with the representative of the employer; Periodic SOP briefing; and Giving reward and punishment to Project Managers and Field Teams.
\end{abstract}

Keywords - Quality Function Deployment, construction project, customer satisfaction.

\section{INTRODUCTION}

$\mathrm{I}_{\mathrm{r}}^{\mathrm{N}}$ INDONESIA, infrastructure development in various regions emerged as a tangible manifestation of the government's seriousness in increasing capacity and construction capability to become the foundation of national economic development. Indonesia's construction services industry is required to maintain and improve the quality of construction products and services so as not to be left behind by its services users. Construction project is said to be of quality, if there is assurance from the contractor that the project is carried out on time, according to technical specifications as well as the health and safety guarantees and to achieve this and to Ensure the consistency of implementation of project owners require that the chosen contractor must have a system that is able to guarantee that each stage of the project activity will be implemented in accordance with the projects quality plan. This will make competition between construction companies, especially those who serve the development services, maintenance and care of both buildings, buildings and mechanical electrical.

PT. Ekapersada Abadi is one of the construction services company in Indonesia. The company is engaged in various fields, among others:

1. General Contractor and Supplier;

2. Building Maintenance;
3. Industrial Chemicals and Waste Treatment;

4. Mechanical Electrical;

5. Engineering Outsourcing.

PT. Ekapersada Abadi serves medium enterprises and large corporations, both private and governance. As a company that also engaged in the procurement of goods and services established on 03 September year 1988, PT. Ekapersada Abadi provides innovative business solutions to partner companies, who always prioritize quality and trust for the harmonious and sustainable business continuity. The company's goal is to be the main choice for business partners by contributing to each client, exceeding the expected, through professional service and full integrity. In the effort to increase the company's success, PT. Ekapersada Abadi should know how to respond to customers and conduct regular evaluation. This is especially necessary for employers to continuously monitor the progress of a project so that remedial or preventive measures can be known and carried out early. Success PT. Ekapersada Abadi as a construction project organizers in particular infrastructure projects can be measured from the satisfaction of the parties both the task giver and the recipient of the task.

The main problem arises when the employer claims dissatisfaction with the quality of service, such as: The technical specification does not match the needs and expectations, speed and timeliness not in accordance with the plan of implementation of the construction and development costs.

To find out the extent to which construction companies, know, understand, and fulfill the desires of service users, an analysis is carried out aimed at knowing the level of customer satisfaction with construction services. Analysis of the level of customer satisfaction is done by using the Importance Performance Analysis method to analyze the level of importance and performance of a service and the Quality Function Deployment method to determine priorities that must be considered by the company in an effort to increase customer satisfaction on services provided by construction companies

\section{METHODS}

In this research the identification that will be carried out is at PT. Ekapersada Abadi, which is to determine customer satisfaction with the services provided by PT. Ekapersada Abadi.

Collection of customer satisfaction data obtained by questionnaire and interview methods. The questionnaire was arranged based on service attributes. This questionnaire contains the level of importance and customer satisfaction with service attributes owned by the contracting company. Respondents in this study are consumers who use 
The $1^{\text {st }}$ International Conference on Business and Engineering Management (IConBEM 2020)

February $1^{\text {st }} 2020$, Institut Teknologi Sepuluh Nopember, Surabaya, Indonesia

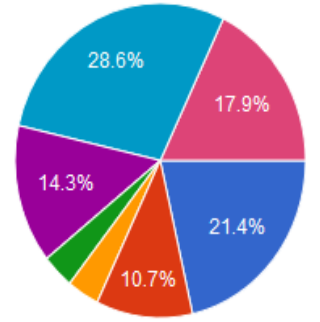

Figure 1. Characteristics of Respondents Based on Position.

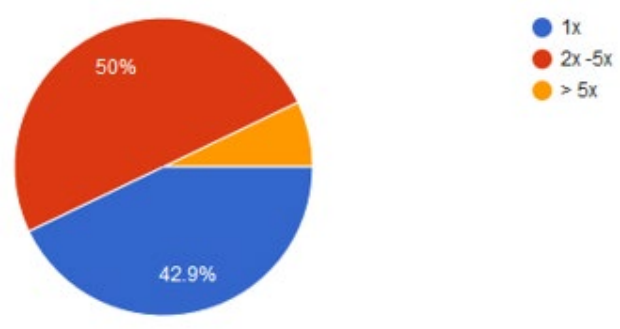

Figure 2. Number of Consumer Collaboration with PT. Ekapersada Abadi

Table 1.

Perception and Expectation Validity Test

\begin{tabular}{|c|c|c|c|c|c|c|c|c|c|c|c|c|c|}
\hline \multirow{2}{*}{ No } & \multirow{2}{*}{ Dimension } & \multirow{2}{*}{ Atribute } & \multicolumn{4}{|c|}{ PERCEPTION VALIDITY TEST } & \multirow{2}{*}{ No } & \multirow{2}{*}{ Dimension } & \multirow{2}{*}{ Atribute } & \multicolumn{4}{|c|}{ EXPECTATION VALIDITY TEST } \\
\hline & & & Pearson & r hitung & $r$ tabel & Status & & & & Pearson & $r$ hitung & $r$ tabel & Status \\
\hline 1 & \multirow{8}{*}{ Responsibilty } & (R1) [Perseption] & 0,42 & 2,054 & 1,734 & VALID & 1 & \multirow{8}{*}{ Responsibilty } & (R1) [Expectation] & 0,41 & 1,986 & 1,734 & VALID \\
\hline 2 & & (R2) [Perseption] & 0,77 & 5,431 & 1,734 & VALID & 2 & & (R2) [Expectation] & 0,66 & 3,961 & 1,734 & VALID \\
\hline 3 & & (R3) [Perseption] & 0,88 & 8,296 & 1,734 & VALID & 3 & & (R3) [Expectation] & 0,75 & 5,085 & 1,734 & VALID \\
\hline 4 & & (R4) [Perseption] & 0,77 & 5,330 & 1,734 & VALID & 4 & & (R4) [Expectation] & 0,68 & 4,150 & 1,734 & VALID \\
\hline 5 & & (R5) [Perseption] & 0,83 & 6,636 & 1,734 & VALID & 5 & & (R5) [Expectation] & 0,49 & 2,521 & 1,734 & VALID \\
\hline 6 & & (R6) [Perseption] & 0,78 & 5,564 & 1,734 & VALID & 6 & & (R6) [Expectation] & 0,53 & 2,820 & 1,734 & VALID \\
\hline 7 & & (R7) [Perseption] & 0,82 & 6,377 & 1,734 & VALID & 7 & & (R7) [Expectation] & 0,53 & 2,820 & 1,734 & VALID \\
\hline 8 & & (R8) [Perseption] & 0,90 & 9,453 & 1,734 & VALID & 8 & & (R8) [Expectation] & 0,57 & 3,128 & 1,734 & VALID \\
\hline 9 & \multirow{7}{*}{ Assurance } & (A1) [Perseption] & 0,75 & 5,099 & 1,734 & VALID & 9 & \multirow{7}{*}{ Assurance } & (A1) [Expectation] & 0,71 & 4,520 & 1,734 & VALID \\
\hline 10 & & (A2) [Perseption] & 0,78 & 5,639 & 1,734 & VALID & 10 & & (A2) [Expectation] & 0,69 & 4,242 & 1,734 & VALID \\
\hline 11 & & (A3) [Perseption] & 0,72 & 4,686 & 1,734 & VALID & 11 & & (A3) [Expectation] & 0,78 & 5,564 & 1,734 & VALID \\
\hline 12 & & (A4) [Perseption] & 0,80 & 5,901 & 1,734 & VALID & 12 & & (A4) [Expectation] & 0,78 & 5,564 & 1,734 & VALID \\
\hline 13 & & (A5)[Perseption] & 0,80 & 5,875 & 1,734 & VALID & 13 & & (A5)[Expectation] & 0,70 & 4,335 & 1,734 & VALID \\
\hline 14 & & (A6) [Perseption] & 0,81 & 6,141 & 1,734 & VALID & 14 & & (A6) [Expectation] & 0,45 & 2,250 & 1,734 & VALID \\
\hline 15 & & (A7) [Perseption] & 0,77 & 5,336 & 1,734 & VALID & 15 & & (A7) [Expectation] & 0,86 & 7,608 & 1,734 & VALID \\
\hline 16 & \multirow{4}{*}{ Tangible } & (T1) [Perseption] & 0,75 & 5,136 & 1,734 & VALID & 16 & \multirow{4}{*}{ Tangible } & (T1) [Expectation] & 0,75 & 5,019 & 1,734 & VALID \\
\hline 17 & & (T2) [Perseption] & 0,60 & 3,388 & 1,734 & VALID & 17 & & (T2) [Expectation] & 0,53 & 2,790 & 1,734 & VALID \\
\hline 18 & & (T3) [Perseption ] & 0,63 & 3,675 & 1,734 & VALID & 18 & & (T3) [Expectation] & 0,53 & 2,790 & 1,734 & VALID \\
\hline 19 & & (T4) [Perseption] & 0,80 & 6,025 & 1,734 & VALID & 19 & & (T4) [Expectation] & 0,76 & 5,275 & 1,734 & VALID \\
\hline 20 & \multirow{4}{*}{ Emphaty } & (E1) [Perseption] & 0,71 & 4,465 & 1,734 & VALID & 20 & \multirow{4}{*}{ Emphaty } & (E1) [Expectation] & 0,67 & 4,081 & 1,734 & VALID \\
\hline 21 & & (E2) [Perseption] & 0,86 & 7,588 & 1,734 & VALID & 21 & & (E2) [Expectation] & 0,84 & 6,903 & 1,734 & VALID \\
\hline 22 & & (E3) [Perseption] & 0,77 & 5,385 & 1,734 & VALID & 22 & & (E3) [Expectation] & 0,84 & 6,903 & 1,734 & VALID \\
\hline 23 & & (E4) [Perseption] & 0,85 & 7,107 & 1,734 & VALID & 23 & & (E4) [Expectation] & 0,61 & 3,486 & 1,734 & VALID \\
\hline 24 & \multirow{6}{*}{ Reliability } & (Re1) [Perseption] & 0,86 & 7,606 & 1,734 & VALID & 24 & \multirow{6}{*}{ Reliability } & (Re1) [Expectation] & 0,50 & 2,600 & 1,734 & VALID \\
\hline 25 & & (Re2) [Perseption] & 0,92 & 10,211 & 1,734 & VALID & 25 & & (Re2) [Expectation] & 0,57 & 3,079 & 1,734 & VALID \\
\hline 26 & & (Re3) [Perseption] & 0,87 & 8,044 & 1,734 & VALID & 26 & & (Re3) [Expectation] & 0,52 & 2,731 & 1,734 & VALID \\
\hline 27 & & (Re4) [Perseption] & 0,51 & 2,654 & 1,734 & VALID & 27 & & (Re4) [Expectation] & 0,54 & 2,906 & 1,734 & VALID \\
\hline 28 & & (Re5) [Perseption] & 0,81 & 6,204 & 1,734 & VALID & 28 & & (Re5) [Expectation] & 0,53 & 2,773 & 1,734 & VALID \\
\hline 29 & & (Re6) [Perseption] & 0,87 & 8,076 & 1,734 & VALID & 29 & & (Re6) [Expectation] & 0,67 & 4,017 & 1,734 & VALID \\
\hline
\end{tabular}

construction services from PT. Ekapersada Abadi with the position of Project Manager, Site Manager, Chief Superintendent, QC, QS, Field Superintendent, and Estate Management with a minimum number of respondents of 20 respondents.

The method used in this research is Voice of customer, Importance-Performance Analysis (IPA), and Quality Function Deployment (QFD).

Voice of customer is based on the dimensions of service quality which results in the identification of gaps. The results of the Voice of customer are translated into a research instrument (questionnaire). Question items used in the study amounted to 29 items which are divided as follows:

1. 8 (eight) question items on the Responsibility dimension;

2. 7 (seven) question items on the Assurance dimension;

3. 4 (four) question items on Tangible dimensions;

4. 4 (four) question items on the Emphaty dimension;

5. 6 (six) question items on the Reliability dimension.

Data analysis begins with the validity test and reliability to see the reliability and consistency of the measuring instrument. That attribute valid and reliable continued to be analyzed by the IPA and QFD methods.

The IPA method has the main function to display information related to service factors which, according to consumers, greatly affect their satisfaction and loyalty, and service factors that according to consumers need to be improved because the current conditions are not yet satisfactory. The IPA combines the measurement of factors of importance and level of satisfaction in a two-dimensional graph that makes it easy to explain data and get practical suggestions. The science chart is divided into four quadrants

QFD method is a method (technique) used to develop design quality that aims to satisfy consumers and translate what consumers want into the design targets and the main quality assurance for use at the production stage

The data analysis steps in this study are as follows:

1. Voice of customer PT. Ekapersada Abadi is known by distributing questionnaires;

2. Perception of interests and customer assessments by IPA;

3. Customer priorities and technical responses are known with QFD. 
The $1^{\text {st }}$ International Conference on Business and Engineering Management (IConBEM 2020)

February $1^{\text {st }} 2020$, Institut Teknologi Sepuluh Nopember, Surabaya, Indonesia

Table 2.

Correlation Coefficient Guidelines

\begin{tabular}{|c|c|}
\hline Magnitude of $\mathbf{r}$ & Value of Interpretation \\
\hline $0,00-0,199$ & Very Low \\
\hline $0,20-0,399$ & Low \\
\hline $0,40-0,599$ & Medium \\
\hline $0,60-0,799$ & Strong \\
\hline $0,80-1,000$ & Very Strong \\
\hline
\end{tabular}

Tables 3.

Perception and Expectation Reability Test

\begin{tabular}{|l|r|r|}
\hline \multicolumn{2}{|l|}{ PERCEPTION REABILITY TEST } \\
\hline Var Total & $\mathbf{4 0 1 , 4 8}$ \\
\hline Alpha & $\mathbf{0 , 9 9 2}$ \\
\hline Status & Reliable \\
\hline
\end{tabular}$;$\begin{tabular}{|l|r|}
\hline Var Total & $\mathbf{1 7 5 , 1 9}$ \\
\hline Alpha & 0,963 \\
\hline Status & Reliable \\
\hline
\end{tabular}

Table 4.

Perception, Performance and GAP of Each Attribute

\begin{tabular}{|c|c|c|c|c|c|c|c|c|}
\hline \multirow[b]{2}{*}{ No } & \multirow[b]{2}{*}{ Dimension } & \multirow{2}{*}{\multicolumn{2}{|c|}{ Atribute }} & \multicolumn{2}{|c|}{ Mean } & \multirow[b]{2}{*}{ Gab } & \multirow{2}{*}{$\begin{array}{c}\text { Level of } \\
\text { satisfaction } \\
\end{array}$} & \multirow[b]{2}{*}{ Ranking } \\
\hline & & & & $\frac{M}{\text { Perseption }}$ & Expection & & & \\
\hline 1 & \multirow{8}{*}{ Responsibilty } & $\mathrm{R} 1$ & $\begin{array}{l}\text { Appropriate quality of work results with } \\
\text { technical specifications }\end{array}$ & 2,750 & 3,850 & $-\quad 1,100$ & $71,43 \%$ & 27 \\
\hline 2 & & $\mathrm{R} 2$ & Fulfillment of construction functions & 3,050 & 4,000 & $-\quad 0,950$ & $76,25 \%$ & 24 \\
\hline 3 & & $\mathrm{R} 3$ & Ability to complete within deadlines & 2,900 & 4,000 & $-\quad 1,100$ & $72,50 \%$ & 27 \\
\hline 4 & & $\mathrm{R} 4$ & $\begin{array}{l}\text { Application of procedures and work } \\
\text { instructions for completing projects }\end{array}$ & 3,050 & 4,000 & $-\quad 0,950$ & $76,25 \%$ & 24 \\
\hline 5 & & R5 & Clarity and time liness into billing & 3,000 & 3,900 & $-\quad 0,900$ & $76,92 \%$ & 23 \\
\hline 6 & & R6 & $\begin{array}{l}\text { Conformity of the project report with } \\
\text { actual conditions on the ground }\end{array}$ & 2,900 & 4,150 & $-\quad 1,250$ & $69,88 \%$ & 29 \\
\hline 7 & & R7 & Total cost usage & 3,350 & 4,150 & 0,800 & $80,72 \%$ & 17 \\
\hline 8 & & R8 & $\begin{array}{l}\text { Cost compliance with the product } \\
\text { produced }\end{array}$ & 3,350 & 4,000 & $-\quad 0,650$ & $83,75 \%$ & 11 \\
\hline 9 & \multirow{7}{*}{ Assurance } & A 1 & $\begin{array}{l}\text { Guaranteed maintenance and quality } \\
\text { assurance of the material used }\end{array}$ & 3,400 & 4,000 & $-\quad 0,600$ & $85,00 \%$ & 9 \\
\hline 10 & & A2 & Service level after completion & 3,200 & 4,100 & 0,900 & $78,05 \%$ & 22 \\
\hline 11 & & A3 & $\begin{array}{l}\text { Scheduled project supervision and quality } \\
\text { control }\end{array}$ & 2,950 & 3,800 & $-\quad 0,850$ & $77,63 \%$ & 19 \\
\hline 12 & & A4 & Company reputation & 3,500 & 3,800 & 0,300 & $92,11 \%$ & 1 \\
\hline 13 & & A5 & $\begin{array}{l}\text { The accuracy of the construction work } \\
\text { method used }\end{array}$ & 3,050 & 3,900 & $-\quad 0,850$ & $78,21 \%$ & 21 \\
\hline 14 & & A6 & $\begin{array}{l}\text { Discipline and compliance with agreed } \\
\text { project schedules }\end{array}$ & 3,200 & 3,950 & $-\quad 0,750$ & $81,01 \%$ & 16 \\
\hline 15 & & A7 & $\begin{array}{l}\text { Conformity of the project scope to the } \\
\text { contract }\end{array}$ & 3,500 & 3,900 & $-\quad 0,400$ & $89,74 \%$ & 2 \\
\hline 16 & \multirow{4}{*}{ Tangible } & $\mathrm{T} 1$ & Material storage is carried out & 3,600 & 4,100 & 0,500 & $87,80 \%$ & 6 \\
\hline 17 & & $\mathrm{~T} 2$ & $\begin{array}{l}\text { Consistency of the quality of the product } \\
\text { produced }\end{array}$ & 3,300 & 3,950 & $-\quad 0,650$ & $83,54 \%$ & 13 \\
\hline 18 & & $\mathrm{~T} 3$ & $\begin{array}{l}\text { Availability of work equipment during the } \\
\text { agreed project period }\end{array}$ & 3,450 & 3,950 & $-\quad 0,500$ & $87,34 \%$ & 7 \\
\hline 19 & & $\mathrm{~T} 4$ & $\begin{array}{l}\text { Project worker expertise in using } \\
\text { equipment in the field }\end{array}$ & 3,200 & 4,050 & $-\quad 0,850$ & $79,01 \%$ & 19 \\
\hline 20 & \multirow{4}{*}{ Emphaty } & E1 & $\begin{array}{l}\text { Services provided by project HRs in } \\
\text { communicating both verbally and in }\end{array}$ & 3,500 & 3,950 & $-\quad 0,450$ & $88,61 \%$ & 3 \\
\hline 21 & & E2 & Level of trust in communication follow-up & 3,150 & 3,950 & $-\quad 0,800$ & $79,75 \%$ & 17 \\
\hline 22 & & E3 & $\begin{array}{l}\text { The presence of on-site company } \\
\text { representatives }\end{array}$ & 3,300 & 3,950 & 0,650 & $83,54 \%$ & 13 \\
\hline 23 & & E4 & $\begin{array}{l}\text { Openness in informing risks (costs, } \\
\text { quality, time, conflicts, etc.) that may }\end{array}$ & 3,300 & 3,750 & 0,450 & $88,00 \%$ & 3 \\
\hline 24 & \multirow{6}{*}{ Reliability } & $\operatorname{Re} 1$ & $\begin{array}{l}\text { Discipline and compliance with relevant } \\
\text { regulations }\end{array}$ & 3,400 & 4,000 & 0,600 & $85,00 \%$ & 9 \\
\hline 25 & & $\operatorname{Re} 2$ & $\begin{array}{l}\text { The ability of a product to add value to its } \\
\text { use }\end{array}$ & 3,250 & 4,200 & 0,950 & $77,38 \%$ & 24 \\
\hline 26 & & $\operatorname{Re} 3$ & Speed in delivery & 3,050 & 3,700 & $-\quad 0,650$ & $82,43 \%$ & 13 \\
\hline 27 & & $\operatorname{Re} 4$ & $\begin{array}{l}\text { Level of knowledge from company } \\
\text { representatives }\end{array}$ & 3,200 & 3,750 & 0,550 & $85,33 \%$ & 8 \\
\hline 28 & & $\operatorname{Re} 5$ & $\begin{array}{l}\text { Responsive level of following up on } \\
\text { requests }\end{array}$ & 3,250 & 3,700 & 0,450 & $87,84 \%$ & 3 \\
\hline 29 & & Re6 & $\begin{array}{l}\text { Frequency of rework / repair during } \\
\text { project implementation }\end{array}$ & 3,200 & 3,850 & 0,650 & $83,12 \%$ & 11 \\
\hline
\end{tabular}

\section{RESULTS AND DISCUSSION}

\section{A. Voice of Customer Analysis (VOC)}

\section{1) Characteristics of Respondents}

Respondents in this study are consumers who use construction services from PT. Ekapersada Abadi with the position of Project Manager, Site Manager, Chief
Superintendent, QC, QS, Field Superintendent, and Estate Management. The results of the distribution of questionnaires, there were 20 respondents who gave their opinions. (Fig. 1)

Based on survey data the number of respondents' collaboration with PT. Ekapersada Abadi is as shown in Figure 2. The largest group of $50 \%$ is in the amount of collaboration between $2 \mathrm{x}-5 \mathrm{x}$ cooperation. The second group 
The $1^{\text {st }}$ International Conference on Business and Engineering Management (IConBEM 2020)

February $1^{\text {st }} 2020$, Institut Teknologi Sepuluh Nopember, Surabaya, Indonesia

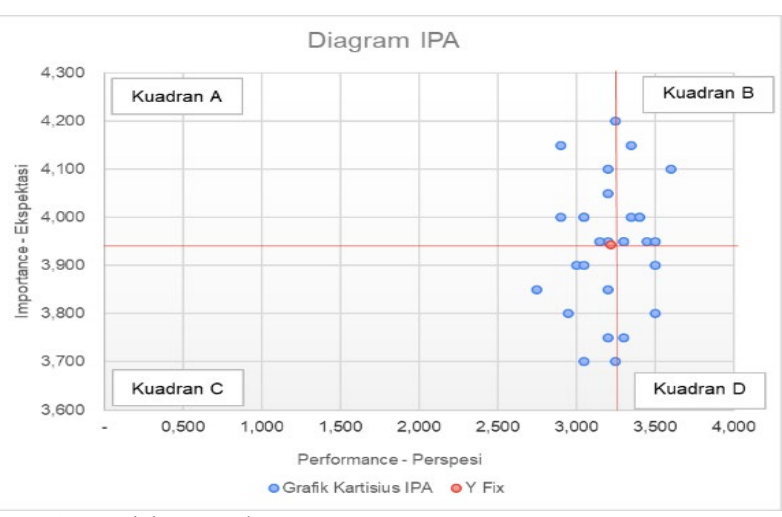

Figure 3. Kartisius Graph.

Tables 6.

Consumer Needs (What) Matrix

\begin{tabular}{|l|l|l|}
\hline & R2 & Fulfillment of construction functions \\
\cline { 1 - 3 } & R3 & Ability to complete within deadlines \\
\cline { 2 - 3 } & R4 & $\begin{array}{l}\text { Application of procedures and work instructions for } \\
\text { completing projects }\end{array}$ \\
\cline { 2 - 3 } & R6 & $\begin{array}{l}\text { Conformity of the project report with actual conditions } \\
\text { on the ground }\end{array}$ \\
\hline & A2 & Service level after completion \\
\cline { 2 - 3 } & A6 & $\begin{array}{l}\text { Discipline and compliance with agreed project } \\
\text { schedules }\end{array}$ \\
\hline & T4 & Project worker expertise in using equipment in the field \\
\hline & E2 & Level of trust in communication follow-up \\
\hline
\end{tabular}

was $42.90 \%$ with the amount of collaboration as much as $1 \mathrm{x}$. And by $7.10 \%$ is the group of respondents who only cooperated with PT. Ekapersada Abadi.

2) Validity and Reliability Test

Reliability and consistency of measuring instruments (questions) customer satisfaction questionnaire can be known from the results of the validity and reliability test.

To test the validity of perceptions and expectations can be seen in Table 1 and Table 2. Tests are performed with Pearson Product Moment for each attribute. Measuring instruments are said to be valid if the results of the correlation value $r$ count $>\mathrm{r}$ table. The statistical formula used for testing validity is the Product Moment Correlation Coefficient Statistics.

$$
\frac{n \sum X Y-\sum X \sum Y}{\sqrt{n \sum X^{2}-\left(\sum X\right)^{2}} \sqrt[n]{\sum Y^{2}-\left(\sum Y\right)^{2}}}
$$

Where:

$\mathrm{N}=$ Number of subjects (respondents)

$\sum X=$ Number of $X$ (item scores)

$\sum X^{2}=$ Number of items squared

$\sum \mathrm{Y}=$ Number of $\mathrm{Y}$ (item scores)

$\sum Y^{2}=$ Number of factors squared score

$\sum X Y=$ Number of times $X \& Y$

Table 1 and Table 2 show that all of the attributes in the perception and expectation variables in the questionnaire were valid.

While the reliability test is used to determine the extent to which a measuring instrument can provide consistent measurement results. The reliability test was conducted using the internal consistency reliability approach, namely the Cronbach alpha method. This method can estimate the relationship or correlation between questions in the questionnaire. Measuring instruments are said to be reliable where the Cronbach's alpha value $(\alpha c)$ matches the
Table 5.

Atribute Each Quadrant

\begin{tabular}{|c|c|c|c|}
\hline \multicolumn{2}{|r|}{$\begin{array}{c}\text { QUADRANT A (27,59\%) } \\
\text { (Concentrate Here) }\end{array}$} & \multicolumn{2}{|r|}{$\begin{array}{l}\text { QUADRANT B }(34,48 \%) \\
\text { (Keep up the good work) }\end{array}$} \\
\hline R2 & $\begin{array}{l}\text { Fulfillment of construction } \\
\text { functions }\end{array}$ & R7 & Total cost usage \\
\hline R3 & $\begin{array}{l}\text { Ability to complete within } \\
\text { deadlines }\end{array}$ & R8 & $\begin{array}{l}\text { Cost compliance with the product } \\
\text { produced }\end{array}$ \\
\hline R4 & $\begin{array}{l}\text { Application of procedures and } \\
\text { work instructions for completing } \\
\text { projects }\end{array}$ & A1 & $\begin{array}{l}\text { Guaranteed maintenance and quality } \\
\text { assurance of the material used }\end{array}$ \\
\hline R6 & $\begin{array}{l}\text { Conformity of the project report } \\
\text { with actual conditions on the } \\
\text { ground }\end{array}$ & T1 & Material storage is carried out \\
\hline $\mathrm{A} 2$ & Service level after completion & $\mathrm{T} 2$ & $\begin{array}{l}\text { Consistency of the quality of the } \\
\text { product produced }\end{array}$ \\
\hline A6 & $\begin{array}{l}\text { Discipline and compliance with } \\
\text { agreed project schedules }\end{array}$ & T3 & $\begin{array}{l}\text { Availability of work equipment } \\
\text { during the agreed project period }\end{array}$ \\
\hline $\mathrm{T} 4$ & $\begin{array}{l}\text { Project worker expertise in using } \\
\text { equipment in the field }\end{array}$ & E1 & $\begin{array}{l}\text { Services provided by project HRs in } \\
\text { communicating both verbally and in } \\
\text { writing }\end{array}$ \\
\hline \multirow[t]{3}{*}{ E2 } & $\begin{array}{l}\text { Level of trust in communication } \\
\text { follow-up }\end{array}$ & E3 & $\begin{array}{l}\text { The presence of on-site company } \\
\text { representatives }\end{array}$ \\
\hline & & $\operatorname{Re} 1$ & $\begin{array}{l}\text { Discipline and compliance with } \\
\text { relevant regulations }\end{array}$ \\
\hline & & $\operatorname{Re} 2$ & $\begin{array}{l}\text { The ability of a product to add value to } \\
\text { its use }\end{array}$ \\
\hline \multicolumn{2}{|r|}{$\begin{array}{l}\text { QUADRANT C (20,69\%) } \\
\text { (Low Priority) }\end{array}$} & \multicolumn{2}{|r|}{$\begin{array}{c}\text { QUADRANT D }(17,24 \%) \\
\text { (Possible Overkill) }\end{array}$} \\
\hline R1 & $\begin{array}{l}\text { Appropriate quality of work results } \\
\text { with technical specifications }\end{array}$ & A4 & Company reputation \\
\hline R5 & Clarity and timeliness into billing & A7 & $\begin{array}{l}\text { Conformity of the project scope to the } \\
\text { contract }\end{array}$ \\
\hline $\mathrm{A} 3$ & $\begin{array}{l}\text { Scheduled project supervision and } \\
\text { quality control }\end{array}$ & E4 & $\begin{array}{l}\text { Openness in informing risks (costs, } \\
\text { quality, time, conflicts, etc.) that may } \\
\text { occur during the project period }\end{array}$ \\
\hline A5 & $\begin{array}{l}\text { The accuracy of the construction } \\
\text { work method used }\end{array}$ & $\operatorname{Re} 5$ & $\begin{array}{l}\text { Tingkat responsive dalam } \\
\text { menindaklaniuti permintaan }\end{array}$ \\
\hline $\operatorname{Re} 3$ & Speed in delivery & $\operatorname{Re} 6$ & $\begin{array}{l}\text { Frekuensi pengerjaan ylang } \\
\text { (rework/repair) selama pelaksaan } \\
\text { provek }\end{array}$ \\
\hline $\operatorname{Re} 4$ & $\begin{array}{l}\text { Level of knowledge from company } \\
\text { representatives }\end{array}$ & & \\
\hline
\end{tabular}

correlation coefficient guidelines listed in Table 2. The alpha conbrach analysis reliability formula is as follows:

$r=\left(\frac{k}{k-1}\right)\left(1-\frac{\sum \sigma_{b}^{2}}{\sigma_{t}^{2}}\right)$

where:

ri $=$ Instrument reliability

$\mathrm{k}=$ The number of questions

$\sum \mathrm{ab}^{2}=$ Number of item variants

$\sigma t^{2}=$ Total variants

The reliability and perception test results in this study get values of 0.992 and 0.963 as listed in Table 4 . These values indicate that all the attributes to be used for analysis are reliable so that they can be used for further analysis.

\section{B. Analysis of the Level of Respondents' Needs (Voice of Customer)}

After testing the validity and reliability of the questionnaire used, the data collection of consumer needs (voice of customer) was carried out on the construction services company PT. Ekapersada Abadi to determine whether the quality of service provided by the company has met customer satisfaction or not. By using the formula:

$\mathrm{Q}=\mathrm{P}$ (perceived service) $-\mathrm{E}($ expected service) 
The $1^{\text {st }}$ International Conference on Business and Engineering Management (IConBEM 2020)

February $1^{\text {st }} 2020$, Institut Teknologi Sepuluh Nopember, Surabaya, Indonesia

Table 7.

Technical Descriptor (Hows)

\begin{tabular}{|c|c|c|c|}
\hline \multicolumn{4}{|c|}{ QUADRANT A } \\
\hline No & $\begin{array}{l}\text { Technical Response } \\
\text { (HOWS) }\end{array}$ & $\begin{array}{c}\text { Code } \\
\text { Atribute }\end{array}$ & Description \\
\hline \multirow{3}{*}{1} & \multirow{3}{*}{$\begin{array}{l}\text { Training of contractor } \\
\text { field supervisors }\end{array}$} & R2 & Fulfillment of construction functions \\
\hline & & R4 & $\begin{array}{l}\text { Application of procedures and work } \\
\text { instructions for completing projects }\end{array}$ \\
\hline & & $\mathrm{T} 4$ & $\begin{array}{l}\text { Project worker expertise in using equipment } \\
\text { in the field }\end{array}$ \\
\hline \multirow{2}{*}{2} & \multirow{2}{*}{$\begin{array}{l}\text { Periodic S Curve } \\
\text { Monitoring }\end{array}$} & R3 & Ability to complete within deadlines \\
\hline & & R6 & $\begin{array}{l}\text { Conformity of the project report with actual } \\
\text { conditions on the ground }\end{array}$ \\
\hline 3 & Periodic SOP briefing & R4 & $\begin{array}{l}\text { Application of procedures and work } \\
\text { instructions for completing projects }\end{array}$ \\
\hline \multirow{4}{*}{4} & \multirow{4}{*}{$\begin{array}{l}\text { Project Control Report } \\
\text { Monitoring Results }\end{array}$} & R6 & $\begin{array}{l}\text { Conformity of the project report with actual } \\
\text { conditions on the ground }\end{array}$ \\
\hline & & R3 & Ability to complete within deadlines \\
\hline & & E2 & Level of trust in communication follow-up \\
\hline & & A2 & Service level after completion \\
\hline 5 & $\begin{array}{l}\text { Improved technical } \\
\text { communication between } \\
\text { the person in charge with } \\
\text { the deputy employer }\end{array}$ & A2 & Service level after completion \\
\hline 6 & $\begin{array}{l}\text { Providing Rewards and } \\
\text { Punishment to Project } \\
\text { Managers and Field } \\
\text { Teams }\end{array}$ & A6 & $\begin{array}{l}\text { Discipline and compliance with agreed } \\
\text { project schedules }\end{array}$ \\
\hline \multirow{2}{*}{7} & \multirow{2}{*}{$\begin{array}{l}\text { Work Equipment Usage } \\
\text { Training }\end{array}$} & $\mathrm{T} 4$ & $\begin{array}{l}\text { Project worker expertise in using equipment } \\
\text { in the field }\end{array}$ \\
\hline & & R2 & Fulfillment of construction functions \\
\hline \multirow{2}{*}{8} & \multirow{2}{*}{$\begin{array}{l}\text { Monitoring the } \\
\text { Communication System } \\
\text { periodically }\end{array}$} & E2 & Level of trust in communication follow-up \\
\hline & & A6 & $\begin{array}{l}\text { Discipline and compliance with agreed } \\
\text { project schedules }\end{array}$ \\
\hline
\end{tabular}

Where:

$\mathrm{Q}=$ quality service

$\mathrm{P}=$ perceived service

$\mathrm{E}=$ expected service

Table 4 is the result of questionnaire data collection related to perceptions, expectations and gaps of each attribute. In this table it is known which attributes make the biggest and smallest contribution by calculating the average consumer perception and the average consumer expectations and the gap (gap) for each attribute. Performance of PT. Ekapersada Abadi on average is less than consumers' expectations (average perception score compared to expectations is 3.217 $<3.943)$.

The gap values in Table 5 can be seen that all attributes are still negative. Where shows consumers have not felt satisfaction with the service system that has been provided by PT. Ekapersada Abadi. Of the 29 (twenty nine) attributes that exist, none has satisfied the company's customers. To improve the performance that has been less good, it is necessary to re-evaluate the efforts that need to be done so that the service system can be better.

\section{Importance Performance Analysis (IPA)}

Analysis of customer satisfaction and the perception of the interests of consumers PT. Ekapersada Abadi is carried out

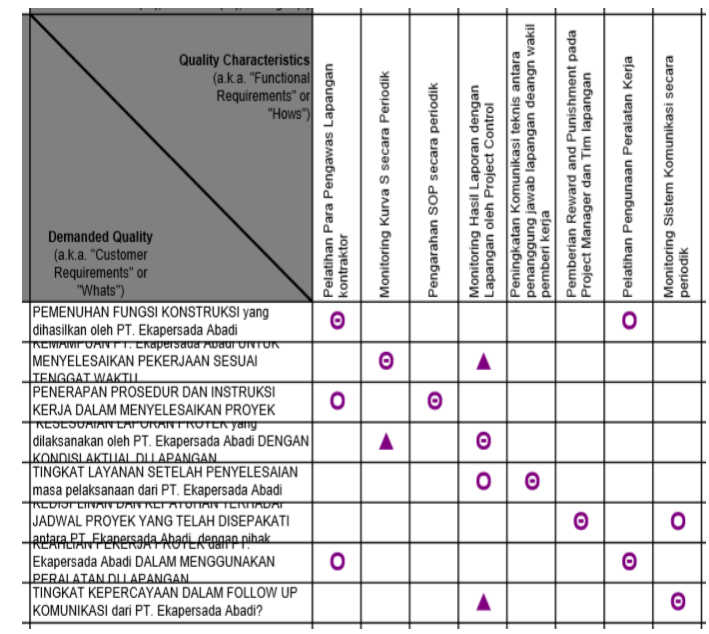

Figure 4. Matrix Relationship between Whats and Hows.

using Importance Performance Analysis (IPA). IPA analysis is used to develop company strategies. The results of processing the IPA data analysis can be seen in Figure 1.

For more details, the attributes included in each awareness can be seen in Table 5 .

Quadrant A (27.59\%) shows that the attributes that are considered to affect consumers, including the elements that are considered top priority but the company has not implemented according to consumer desires, so consumers feel dissatisfied or disappointed.

Quadrant B (34.48\%) shows the achievements that have been successfully carried out by the company, for that the company is required to maintain. Attributes in this quadrant are very important and very satisfying consumers.

Quadrant C (20.69\%) is considered less important by consumers but the company has provided low quality services. Thus this $\mathrm{C}$ quadrant becomes a priority to be improved.

Quadrant D (17.24\%) is less considered important by consumers but the company has provided good quality services. So that the attributes in this quadrant become excessive.

\section{Quality Function Deployment (QFD) \\ 1) Consumer Needs (What)}

The first step in analyzing the Quality Function Deployment (QFD) method is to arrange the customer requirements matrix. In the IPA method, which falls into the consumer needs matrix is quadrant A (concentrate here), because the attributes in this quadrant are prioritized by the company PT. Ekapersada Abadi. In Table 6 illustrates the desire or willingness of consumers for existing services.

2) Technical Descriptor (Hows)

At this stage it is the service phase that provides answers in the form of technical engineering (Hows). Technical engineering is a response from the company PT. Ekapersada Abadi to the desires of its consumers. This technical engineering was obtained by the company through a discussion forum better known as a Focus Group Discussion (FGD).

FGD is a form of discussion that is designed to bring up information about wants, needs, points of view, beliefs and experiences desired by participants. The number of FGD participants is around 7-10 people with participants from 
The $1^{\text {st }}$ International Conference on Business and Engineering Management (IConBEM 2020)

February $1^{\text {st }} 2020$, Institut Teknologi Sepuluh Nopember, Surabaya, Indonesia

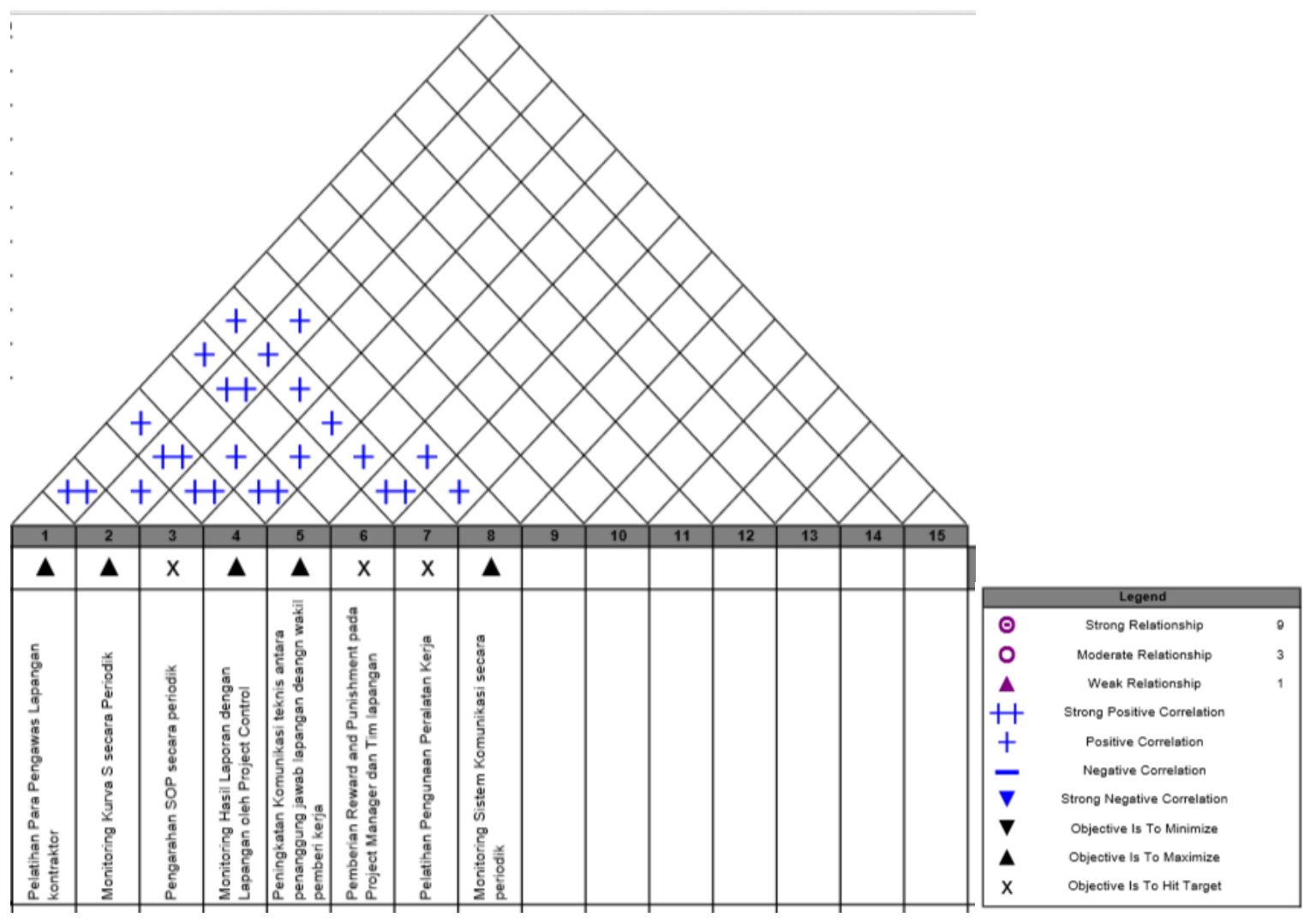

Figure 5. Relationship Between Hows Matrix

Table 8.

Prioritized Customer Requirements

\begin{tabular}{|c|c|c|c|c|c|c|c|c|c|}
\hline \multicolumn{5}{|c|}{ QUADRANT A } & \multirow{2}{*}{\begin{tabular}{|c}
$\begin{array}{c}\text { Improvement } \\
\text { Ratio (IR) }\end{array}$ \\
$\mathbf{c}=(\mathbf{b} / \mathbf{a})$
\end{tabular}} & \multirow{2}{*}{\begin{tabular}{|c|}
$\begin{array}{l}\text { Sales } \\
\text { Point }\end{array}$ \\
d \\
\end{tabular}} & \multirow{2}{*}{$\begin{array}{c}\text { Weight } \\
e=\left(b^{*} c^{*} d\right)\end{array}$} & \multirow{2}{*}{\begin{tabular}{|c|}
$\begin{array}{c}\text { Relative } \\
\text { Weight }\end{array}$ \\
$\mathbf{f}=$ \\
$(\mathbf{e} /$ total*100 \\
$\%)$
\end{tabular}} & \multirow[b]{2}{*}{ Priority } \\
\hline No & $\begin{array}{c}\text { Code } \\
\text { Atribute }\end{array}$ & Description & Perception & Expection & & & & & \\
\hline 1 & (R2) & Fulfillment of construction functions & 3,050 & 4,000 & 1,311 & 1,20 & 6,30 & 10,209 & 8 \\
\hline 2 & (R3) & Ability to complete within deadlines & 2,900 & 4,000 & 1,379 & 1,50 & 8,28 & 13,422 & 2 \\
\hline 3 & (R4) & $\begin{array}{l}\text { Application of procedures and work } \\
\text { instructions for completing projects }\end{array}$ & 3,050 & 4,000 & 1,311 & 1,50 & 7,87 & 12,762 & 4 \\
\hline 4 & (R6) & $\begin{array}{l}\text { Conformity of the project report with } \\
\text { actual conditions on the ground }\end{array}$ & 2,900 & 4,150 & 1,431 & 1,50 & 8,91 & 14,447 & 1 \\
\hline 5 & (A2) & Service level after completion & 3,200 & 4,100 & 1,281 & 1,50 & 7,88 & 12,779 & 3 \\
\hline 6 & (A6) & $\begin{array}{l}\text { Discipline and compliance with agreed } \\
\text { project schedules }\end{array}$ & 3,200 & 3,950 & 1,234 & 1,50 & 7,31 & 11,861 & 7 \\
\hline 7 & (T4) & $\begin{array}{l}\text { Project worker expertise in using } \\
\text { equipment in the field }\end{array}$ & 3,200 & 4,050 & 1,266 & 1,50 & 7,69 & 12,470 & 5 \\
\hline 8 & (E2) & $\begin{array}{l}\text { Level of trust in communication follow- } \\
\text { up }\end{array}$ & 3,150 & 3,950 & 1,254 & 1,50 & 7,43 & 12,050 & 6 \\
\hline
\end{tabular}

various positions, including: Project Manager, Site Manager, Chief Superintendent, QC, QS, Field Superintendent, and Estate Management. The technical engineering produced from the FGD can be seen in Table 7.

3) Developing the Relationship between the Whats Matrix and the Hows Matrix (Fig. 4)

At this stage, it is explained that the Whats matrix is a question and the Hows matrix is the answer, so a relationship between these two matrices will occur. The symbols used in this relationship matrix are:
: strong relationship - rated 9 .

: medium relationship - rated 3 .

$\triangle$ : weak relationship - given a value of 1

4) Develop Relationships Between Hows Matrix

The Hows Matrix is alternative answers to Whats questions which consists of several company policies PT. Ekapersada Abadi. Relationships can influence or conflict with one another. Implementation of the policy taken must pay 
The $1^{\text {st }}$ International Conference on Business and Engineering Management (IConBEM 2020)

February $1^{\text {st }} 2020$, Institut Teknologi Sepuluh Nopember, Surabaya, Indonesia

Table 9

Prioritized Customer Requirements Rank

\begin{tabular}{|c|c|c|}
\hline Priority & $\begin{array}{c}\text { Code } \\
\text { Atribute }\end{array}$ & Description \\
\hline 1 & R6 & $\begin{array}{l}\text { Conformity of the project report with actual } \\
\text { conditions on the ground }\end{array}$ \\
\hline 2 & R3 & Ability to complete within deadlines \\
\hline 3 & A2 & Service level after completion \\
\hline 4 & R4 & $\begin{array}{l}\text { Application of procedures and work instructions } \\
\text { for completing projects }\end{array}$ \\
\hline 5 & $\mathrm{~T} 4$ & $\begin{array}{l}\text { Project worker expertise in using equipment in the } \\
\text { field }\end{array}$ \\
\hline 6 & E2 & Level of trust in communication follow-up \\
\hline 7 & A6 & $\begin{array}{l}\text { Discipline and compliance with agreed project } \\
\text { schedules }\end{array}$ \\
\hline 8 & R2 & Fulfillment of construction functions \\
\hline
\end{tabular}

attention to this aspect. If the policies taken are mutually supportive, it will certainly be very beneficial in achieving the goals. But if the policies taken are conflicting, then the results to be achieved will not be optimal. For more details, can be seen in Figure 5.

\section{5) Develop Prioritized Customer Requirements}

At this stage, the level of customer satisfaction with PT. Ekapersada Abadi. The steps taken are to calculate goals, improvement ratio of sales point value, row weigt and normalized row weight. The results of all calculations can be seen in Table 8.

This goal is determined by the company so that the improvement target to be achieved is clearer and reaches the target. To determine goals, calculated through improvement ratio. Improvement ratio is the ratio value between the goals to be achieved (goals) with the level of customer satisfaction with company performance.

After calculating the improvement ratio, the next step is to calculate the sales point. Sales points are given on attributes expected by consumers. The value of this sales point is calculated as input to calculate row weight in the next step. The value of sales points can be seen in the previous chapter.

Table 9 shows the value of sales points for all attributes that are the top priority. Attribute (R2) has a sales point value of 1.2 because this attribute is less able to improve service from the company. As for the other attributes (R3, R4, R6, A2, A6, T4 and E2) have a sales point value of 1.5, which means these attributes can be superior so that it can improve company services to achieve customer satisfaction.

After knowing, the next step is to calculate row weigt and normalized row weight. Row weigt is a weight for each line of consumer attributes which is the basis for evaluating the determination of priority fulfillment of the needs and desires of consumers. Row weight is calculated by the formula:

$$
R W i=I W i \times S P i \times I R i
$$

where:

RWi $=$ Row Weight attribute $\mathrm{i}$

IWi $=$ Weight of importance for consumer attributes $\mathrm{i}$

$\mathrm{SPi}=$ Sales point for consumer attributes $\mathrm{i}$

$\mathrm{IRi}=$ Improvement ratio of consumer attributes $\mathrm{i}$

This priority is made based on the level of consumer interest, the final goal to be achieved. Current conditions of consumer satisfaction performance and sales points. The results of row weigt calculation and normalized row weight can be seen in Table 9 and can be seen the priority level of the needs or desires of consumers as listed in Table 9.
Table 10

Priorized Technical Descriptors Rank

\begin{tabular}{|c|l|}
\hline Priority & \multicolumn{1}{c|}{ Description } \\
\hline 1 & Project Control Report Monitoring Results \\
\hline 2 & Training of contractor field supervisors \\
\hline 3 & Monitoring the Communication System periodically \\
\hline 4 & Work Equipment Usage Training \\
\hline 5 & Periodic S Curve Monitoring \\
\hline 6 & $\begin{array}{l}\text { Improved technical communication between the person in } \\
\text { charge with the deputy employer }\end{array}$ \\
\hline 7 & Periodic SOP briefing \\
\hline 8 & $\begin{array}{l}\text { Providing Rewards and Punishment to Project Managers and } \\
\text { Field Teams }\end{array}$ \\
\hline
\end{tabular}

6) Develop Priorized Technical Descriptors

At this stage will be discussed related to the level of difficulty that may be experienced by the company in carrying out certain policies in connection with consumer demands. The greater the value of the difficulty level of a technical response, the more difficult the policy is implemented. The formula used to calculate degree if diffculty, target value, absolute weight percent and relative weight percent has been discussed in the previous chapter. The calculation results from priorized technical descriptors can be seen in Table 10 .

Based on the Table 10, it can be seen which technical responses need to be prioritized first by PT. Ekapersada Abadi to improve and improve service quality so that it can compete with other construction service companies. For more details the sequence of technical responses to handle the voice of customer can be seen in Table 10.

\section{E. Company Development Strategy}

The combination of the above stages is put together into a matrix called the House of Quality (HoQ) matrix as shown in Figure 4.

Based on the above analysis, it is known the priority of consumer needs and the company's technical response listed in the HoQ matrix. The company's development strategy will be taken by PT. Ekapersada Abadi in order to improve the quality of its services by:

1. Improving the understanding of HR on work results;

2. Monitoring all projects well;

3. HR who understands and understands SOP;

4. Reports are true and valid;

5. Good communication ties;

6. Creation of discipline in HR projects;

7. The correct use of work equipment;

8. The level of company trust increases

Numerals of five or more digits are grouped in three-digit blocks by spaces, e.g. 12,345 (if written in English) or 12.345 (if written in Bahasa Indonesia). Pay attention a significant figure and avoid an unnecessary long digit number.

\section{CONCLUSIONS}

Based on the results of research and discussion, the results achieved in this study are in accordance with the objectives of the study, which are as follows:

a. Consumer satisfaction in this study is based on service quality attributes in quadrant A (top priority), namely the suitability of the project report with actual conditions in the field; Ability to complete within deadlines; Service level after completion; Application of work procedures 
The $1^{\text {st }}$ International Conference on Business and Engineering Management (IConBEM 2020)

February $1^{\text {st }} 2020$, Institut Teknologi Sepuluh Nopember, Surabaya, Indonesia

and instructions for completing projects; Project worker expertise in using equipment in the field; Level of trust in communication follow-up; Discipline and compliance with agreed project schedules and Fulfillment of construction functions

b. Technical response which is a priority of the company's strategy in improving company performance in the next construction project is Monitoring the results of the field report by Project Control; Training of contractor field supervisors; Monitoring the communication system periodically; Training in the use of work equipment; Periodic S curve monitoring; Improved technical communication between the person in charge with the representative of the employer; Periodic SOP briefing; and Giving reward and punishment to Project Managers and Field Teams.

\section{V.REFERENCES}

[1] A Parasuraman, v. A. (1990). "Delivering Quality Service : Balancing Customer Perception and Expectations". The Free Press.

[2] Akao, Y. (1997). Past, Present and Future. International Symposium on QFD'97.

[3] Carpenter, S. H. (2003). Qualitative research in nursing: Advancing the humanistic imperative. Philadelphia: Lippincott.

[4] Ervianto, W. I. (2005). Manajemen Proyek Konstruksi. Yogyakarta: Andi Offset.

[5] Henny Yunit, A. S. (2017, Juni). Analisis Tingkat Kepuasan Pengguna Jasa Konstruksi Terhadap Penerapan Sistem Manajemen Mutu Iso 9001:2008 Di Perusahaan Jasa Konstruksi. Jurnal Infrastruktur, Vol. 3 No. 01 .

[6] Ikrimah Nur Azizah, R. L. (2018, Agustus). Penerapan Metode Quality Function Deployment dalam Memenuhi Kepuasan Konsumen pada
Industri Komponen Otomotif. Jurnal Teknik Industri, Vol. 19, No. 2 , pp. 127-136. Diambil kembali dari https://doi.org/10.22219/JTIUMM.Vol19.No2.127-136

[7] Kano, N. (1993). Special issue on Kano's methods for understanding customer-defined quality. Journal of Quality Management .

[8] Kitzinger, J. (1994). The methodology of focus group interviews: the importance of interaction between research participants. Sociology of Health and Illness, 16, 103-121.

[9] Lehoux, P. P. (2006). Focus group research and "the patient's view. Social Science \& Medicine, 63, 2091-2104.

[10] Lipke, W. (2013). Is Something Missing from Project Management. CrossTalk, 25th Anniversary Issue, hal. 16-20.

[11] Lupiyoadi, R. (2001). Manajemen Pemasaran Jasa: Teori dan Praktik. Jakarta: PT. Salemba Emban Patria.

[12] Manlian Ronald A. Simanjuntak, A. K. (2017). Analisis Indikator Kepuasan Proyek Konstruksi Bangunan Terhadap Kinerja Biaya, Mutu Dan Waktu. Konferensi Nasional Teknik Sipil 11. Universitas Tarumanagara.

[13] Mark A. Vonderembse, T. R. (1997, December 1). Quality function deployment's impact on product development. International Journal of Quality Science, Vol. 2 No. 4, pp. 253-271.

[14] Martila, J. A. (1977). Importance Performance Analysis. Journal of Marketing, pp. 77.

[15] Osaliana Budiarto, I. M. (t.thn.). Analisis Kepuasan Pelanggan PT. Wijaya Karya (Persero) Tbk Pada Proyek Pembangunan Di Provinsi Kalimantan Timur. Institut Teknologi Sepuluh Nopember, Jurusan Statistika, Fakultas MIPA, Surabaya.

[16] PMI, P. M. (2000). A Guide to the Project Managemet Body of Knowledge. Pennsylvania, Four Campus Boulevard: Edition Newtown Square.

[17] Suharto, I. (1999). Manajemen Proyek dari Konseptual sampai Operasional) Jilid 1 (Vol. Edisi kedua). Jakarta,: Penerbit Erlangga.

[18] Tjiptono, F. (2001). Manajemen Jasa.

[19] Ulrich, K. T. (2001). Perancangan \& Pengembangan Produk. Jakarta: Salemba Teknika.

[20] Winarsih., R. \&. (2009). Manajemen Pelayanan: Pengembangan Model Konseptual, Penerapan Citizen's Charter dan Standar Pelayanan Minimal. Yogyakarta: Pustaka Pelajar 